\title{
IMPLEMENTASI AUTO VOLTAGE REGULATOR PADA SISI BEBAN ENERGI LISTRIK
}

\author{
Nur liya ${ }^{1}$, Abdul Muis Prasetia ${ }^{2}$ \\ 1,2 Jurusan Teknik Elektro Univesitas Borneo Tarakan, Kalimantan Utara \\ 105nurliya@gmail.com \\ ${ }^{2}$ prasetia.electricegmail.com
}

\begin{abstract}
Electrical energy is one of the basic needs in the present era, most human activities require electrical energy, so an increase in the need for electrical energy also increases, resulting in increased system problems. Voltage instability can also result in system problems and poor quality of electrical power. With a protection system, devices related to electricity will be safe and avoid damage. Auto Voltage Regulator is used to improve the voltage value at the point where the tool is installed. Auto Voltage Regulator (AVR) which is often used is a type of autotransformator. In this study, the PWM (Pulse Width modulation) dimmer is implemented as an AVR. Dimmer is an electronic circuit that modifies the form of a pure $A C$ (Alternative Current) signal into a modulated signal so that the output voltage can be adjusted. The results of the test by providing a variety of different voltage input values. The system is obtained by providing an input value of 195 with a system output of 194, but if the system is given an input above the Set Point, the system is able to reduce the voltage up to 220 volts.
\end{abstract}

Keywords-Voltage instability, Automatic Voltage Regulator (AVR), electrical energy.

Intisari- Energi listrik merupakan satu dari kebutuhan pokok di era sekarang, sebagian besar aktifitas manusia membutuhkan energi listrik, Maka peningkatan akan kebutuhan energi listrik pun bertambah, mengakibatkan permasalahan pada sistem bertambah. Ketidakstabilan pada tegangan dapat mengakibatkan pula permasalahan pada sistem dan buruknya kualitas daya listrik. Adanya sistem proteksi maka perangkat yang berhubungan dengan listrik akan menjadi aman dan terhindar dari kerusakan. Auto Voltage Regulator digunakan untuk memperbaiki nilai tegangan pada titik dimana alat itu dipasang. Auto Voltage Regulator (AVR) yang sering digunakan merupakan tipe autotransformator. Pada penelitian ini mengimplementasikan dimmer PWM (Pulse Width modulation) sebagai AVR. Dimmer merupakan rangkaian elektronika yang memodifikasi bentuk sinyal AC (Alternative Current) murni menjadi sinyal termodulasi sehingga tegangan keluaran dapat diatur. Hasil dari pengujian dengan memberikan berbagai macam nilai masukkan tegangan yang berbeda-beda. Didapatkan sistem dengan memberikan nilai input sebesar 195 dengan keluaran sistem juga sebesar 194, tetapi bila sistem diberikan masukkan diatas Set Point maka sistem mampu menurunkan tegangan sampai dengan 220 volt.

Kata Kunci-Ketidakstabilan tegangan, Automatic Voltage Regulator (AVR), energi listrik.

\section{PENDAHULUAN}

Auto Voltage Regulator digunakan untuk memperbaiki nilai tegangan pada titik dimana alat itu dipasang. Auto Voltage Regulator (AVR) pada dasarnya merupakan sebuah autotransformator dengan banyak tap pada sisi sekundernya. Komponen utamanya adalah mekanisme tap changing dan pengendaliannya. Tiap Auto Voltage Regulator (AVR) biasanya dilengkapi oleh peralatan yang bisa mengendalikan perubahan tap secara otomatis berdasarkan tegangan yang masuk walaupun pada saat itu Auto Voltage Regulator (AVR) dalam keadaan berbeban[1]. Tetapi desain atau peralatan tersebut membutuhkan ruang yang besar dengan kata lain bentuk dari AVR memiliki body yang cukup besar.

Dimmer merupakan rangkaian elektronika yang memodifikasi bentuk sinyal AC (Alternative Current) murni menjadi sinyal termodulasi sehingga tegangan keluaran dapat diatur. Dimmer yang lebih komplek menggunakan PWM (Pulse Width Modulaion) sebagai pengendalinya. Dimmer PWM ini mampu menghasilkan tingkatan daya yang kecil sebesar, 0.025 Watt sehingga pengendalian menjadi lebih presisi. Berdasarkan permasalahan yang diuraiakan pada paragraf sebelumnya maka peneliti akan mendesain alat AVR dengan menggunakan dimmer. Dimana desain AVR dengan menggunakan dimmer lebih kecil dibandingkan dengan tipe autotransformator

\section{LANDASAN TEORI}

\section{A. Zero Crossing Detector}

Zero crossing detector adalah rangkaian yang digunakan untuk mendeteksi gelombang sinus AC 220 Volt saat melewati titik nol. Seberangan titik nol yang dideteksi adalah peralihan dari positif menuju negatif dan peralihan negatif menuju positif [2][3]. Rangkaian zero crossing berfungsi untuk mengkonversi sinyal sinusoida arus dan tegangan menjadi sinyal step.

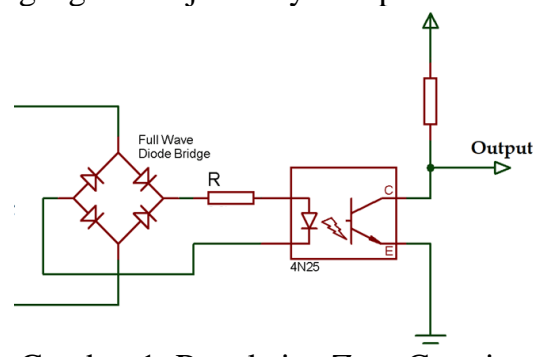

Gambar 1. Rangkaian Zero Crossing 


\section{B. Dimmer}

Dimmer adalah rangkaian elektronik yang memodifikasi bentuk sinyal ac murni menjadi sinyal terpotong-potong sehingga daya keluaran bisa diatur. Pemotongan sinyal ac ini berguna sebagai peredup lampu, memperlambat motor, mengatur pemanasan dan lainnya. Dimmer yang lebih komplek menggunakan PWM (Pulse Width Modulaion) sebagai pengendalinya. PWM bisa dihasilkan oleh rangkaian SCR, chip/IC PWM atau mikrokontroller. Dimmer PWM ini mampu menghasilkan tingkatan daya yang kecil, sehingga pengendalian menjadi lebih presisi. Dimmer PWM bisa dikategorikan menjadi dua macam yaitu:

1) Penyalaan berdasarkan titik nol.

Waktu penyalaan bergantung pada saat sinyal menyentuh nilai nol. Maka dibutuhkan mekanisme untuk mendeteksi waktu sinyal tersebut bernilai 0 . Komponen Silicon Controller Rectifier (SCR) memiliki sifat forward blocking, forward conduction, dan reverse blocking, maka komponen ini cocok digunakan sebagai dimmer elektronik. Pada aplikasi dimmer digital, perlintasan titik nol harus dideteksi terlebih dahulu sebelum melakukan menyalaan, Pendeteksian nilai nol bisa dilakukan dengan rangkaian zero crossing detector.

2) Penyalaan Bebas

Waktu penyalaan dimmer tidak dipengaruhi oleh nilai nol, pengaturan dimmer PWM lebih diutamakan pada frekuensi PWM-nya. Dimmer lampu akan terlihat berkedip jika frekuensi tidak sama. Untuk mengatasi permasalahan tersebut rangkaian peredup lampu (dimmer) didesain dengan penggunaan frekuensi yang lebih tinggi dari frekuensi sinyal AC tanpa memperhatikan waktu nol dan nilai frekuensinya.

\section{METODE PENELITIAN}

\section{A. Metode Penelitian}

Pada penelitian ini melakukan beberapa metode diantaranya ialah :

1. Studi Literatur yaitu mengumpulkan beberapa literatur yang berkaitan dengan dengan penelitian ini diantaranya jurnal-jurnal ilmiah, buku referensi dan sumber-sumber lainya.

2. Perancangan sistem AVR (Auto Voltage Regulator). Pada metode ini memfokuskan peneliti untuk merancang dari sistem AVR. Perancangan sistem terdiri dari alat-alat yang dibutuhkan dan dihubungkan dimulai dari dimmer, sensor dan mikrokontroler.

3. Perancangan program mengenai alat AVR (Auto Voltage Regulator), pada perancangan program peneliti menggunakan mikrokontroler dimana program yang digunakan Bahasa program yang sekiranyan dimengerti oleh sistem dan tepat.

4. Pengujian pertama yaitu menguji hardware yang digunakan. Pengujian ini berfungsi untuk mengetahui apakah hardware dalam kondisi bagus, dapat difungsikan dengan baik untuk sistem AVR.

5. Pengujian terakhir menggabungkan hardware sesuai dengan sistem dan dilakukan pengujian keseluruhan untuk mengetahui apakah sistem sudah sesuai dengan tujuan dari penelitian yang dilakukan. Analisis hasil pengujian melakukan analisis hasil pengujian untuk memperoleh kinerja sistem secara keseluruhan dan mengklarifikasi hasil tersebut terhadap tujuan yang telah ditetapkan. Apabila belum memenuhi tujuan maka perlu dikaji lebih lanjut

6. Mengenai gagasan alternatif agar tujuan yang telah ditetapkan dapat dicapai.

7. Penarikan kesimpulan jika hasil evaluasi menunjukkan bahwa tujuan penelitian telah tercapai maka akan ditarik kesimpulan untuk menegaskan bahwa gagasan yang diusulkan berhasil menyelesaikan permasalahan dan memenuhi tujuan penelitian.

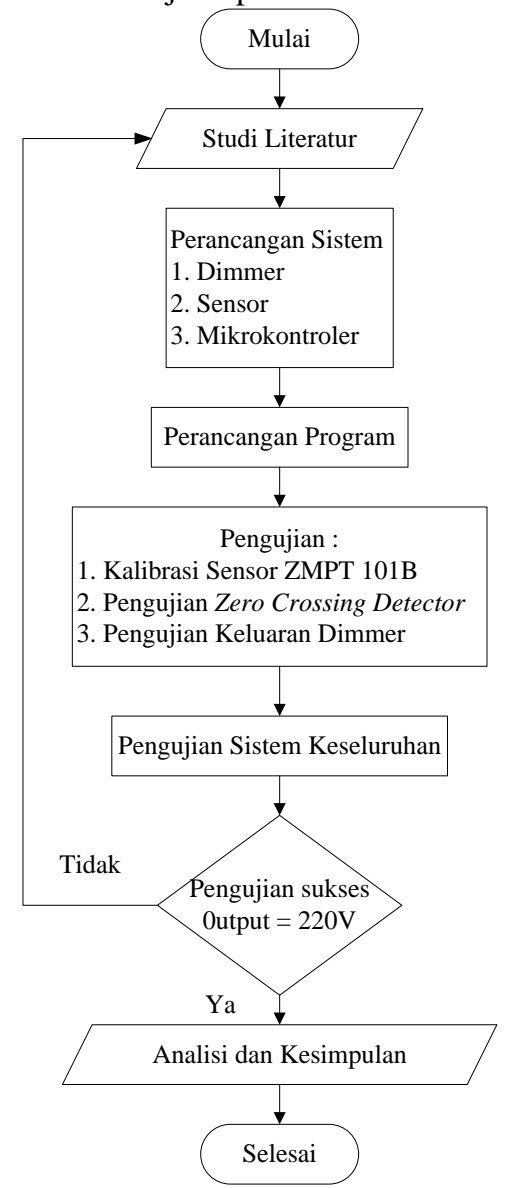

Gambar 2. Diagram alir penelitian

B. Perancangan Sistem

Gambar 3 merupakan diagram blok sistem perancangan peralatan sederhana :

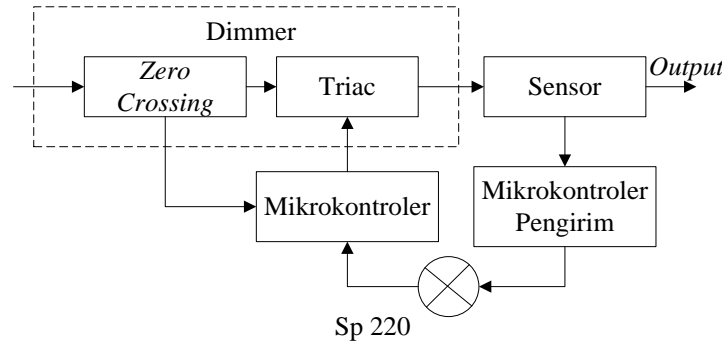

Gambar 3. Diagram blok perancangan sistem

Sistem diatas merupakan gambaran umum dari perancangan alat dimana komponen utama dari sistem merupakan dimmer yang terdiri dari zero crossing detector dan Triac. Tegangan awal akan langsung diinputkan pada dimmer bila output dari dimer belum sesuai dengan setpoint terbaca melalui sensor tegangan yang dipasang 
pada output dimmer dan data tersebut akan dikirim pada mikrokontroler utama hasil dari data tersebut akan menjadi nilai error untuk menjadi inputan dimmer dan dimmer akan menurunkan nilai tegangan hal ini akan berlanjut sampai nilai tegangan yang diinginkan. Pada gambar 4 merupakan diagram alir dari program

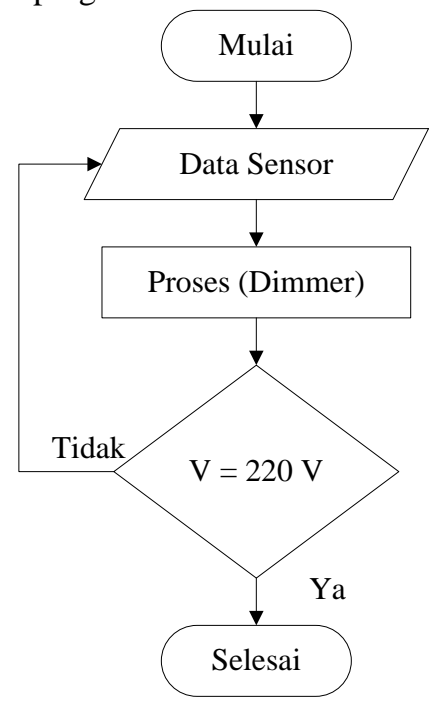

Gambar 4. Diagram alir program

Program dari sistem belum menggunakan metode. Data yang dimaksud pada gambar yaitu pembacaan dari sensor ZMPT101B. Proses melakukan pengolahan data dari sensor, data yang diterima akan menjalankan dimmer untuk menurunkan nilai tegangan ketika belum mencapai $220 \mathrm{~V}$ makan akan diproses ulang sampai dengan tegangan $220 \mathrm{~V}$ dan selesai.

\section{Tahapan Pengujian}

Dalam penelitian ini memiliki beberapa pengujian. Tujuan dari pengujian ini untuk mengetahui tingkat keberhasilan alat yang dibuat. Adapun persamaan yang digunakan sebagai berikut. Beberapa pengujian yang dilakukan sebagai berikut:

1) Kalibrasi dan Pengujian Sensor Tegangan

Sensor yang dapat bekerja dengan baik yaitu sensor yang memiliki sifat linieritas yang baik, artinya nilai output dari sensor akan naik ataupun turun sesuai dengan naik atau turunnya input dari sensor. Untuk menentukan tingkat linieritas sensor dapat dilakukan dengan mencari koefisien korelasi antara input dan output dari sensor.

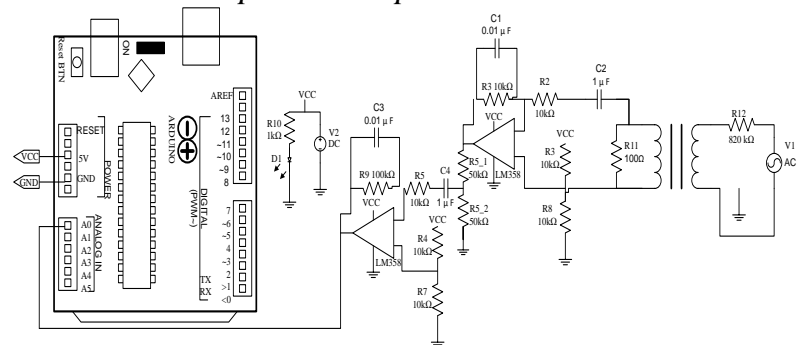

Gambar 5. Rangkaian sensor

\section{2) Pengujian Zero Crossing Detector}

Zero crossing detector merupakan rangkaian elektronik yang berfungsi untuk mendeteksi persilangan nol yang ada pada tegangan AC. Rangkaian Zero Crossing Detector akan memberikan output berupa pulsa sempit pada saat terjadi persilangan nol pada tegangan $\mathrm{AC}$ yang di deteksi.
Rangkaian zero crossing detector berfungsi untuk mendeteksi perpotongan gelombang sinus dengan zero point pada tegangan $\mathrm{AC}$, sehingga dapat menentukan waktu acuan pada TRIAC dan menentukan posisi perubahan tegangan. Dengan menggunakan rangkaian Zero crossing detector ini, kita dapat mendeteksi zero point sekaligus mengubah suatu sinyal sinusoida menjadi sinyal kotak. Perpotongan titik nol yang terdeteksi adalah pada saat peralihan dari siklus positif menuju siklus negative dan peralihan dari siklus negative menuju siklus positif. Sinyal acuan (zero point) akan digunakan sebagai interupsi eksternal mikrokontroller dan selanjutnya mikrokontroller akan mengatur dan membangkitkan sinyal PWM untuk memicu gate TRIAC.

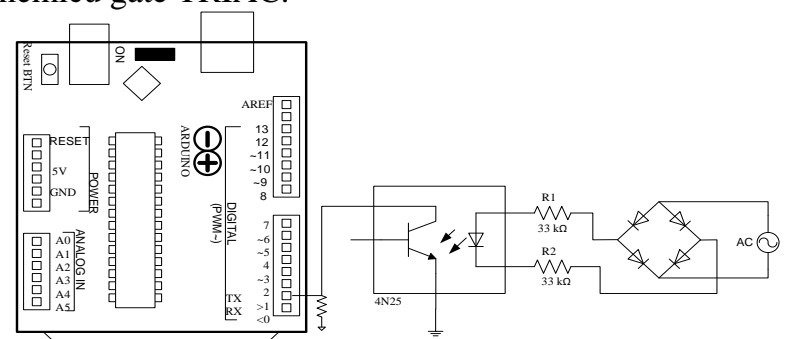

Gambar 6. Skematik Pengujian Zero Crossing Detektor

3) Pengujian keluaran dimmer

Pengujian ini dilakukan untuk mengetahui keluaran sinyal dimmer pengaruh terhadap frekuensi dan tegangan sinyal keluaran. Rangkaian pengujian dimmer terlihat pada gambar 7.

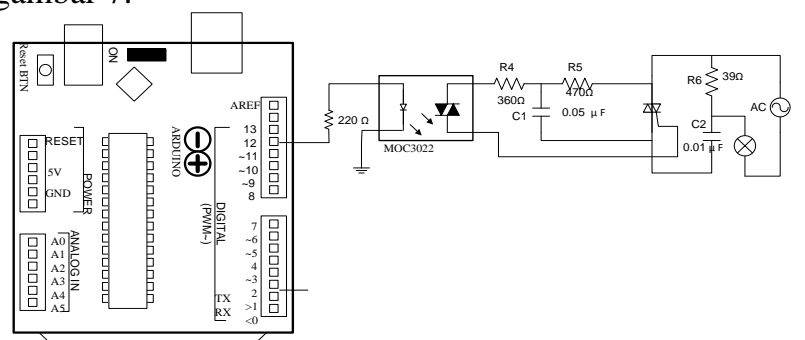

Gambar 7. Rangkaian Pengujian Dimmer

4) Pengujian sistem secara keseluruhan

Dalam pengujian keseluruhan yang di maksud ialah pengujian keluaaran AVR (Auto Voltage Regulator) terhadap beban lampu. Pengujian ini diharapkan AVR (Auto Voltage Regulator) dapat menurunkan tegangan dengan frekuensi $50 \mathrm{~Hz}$ dan gelombang sinus. Pengujian ini menggunakan multimeter digital dan membandigkannya dengan output. 


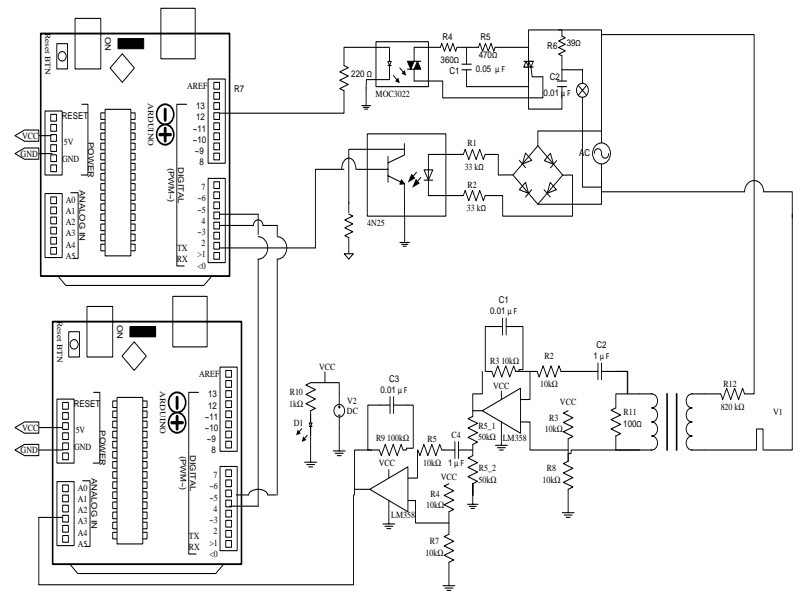

Gambar 8. Rangkaian Pengujian Keseluruhan

\section{HASIL DAN PEMBAHASAN}

Hasil pada bab ini didapatkan dari metode penelitian yang telah dilakukan terhadap rancangan alat untuk mengetahui apakah tujuan dari perancangan alat dari sistem dapat berjalan dengan baik.

\section{A. Kalibrasi dan Pengujian Sensor Tegangan}

Dalam membuat sebuah alat digital, sensor-sensor yang digunakan terlebih dahulu dikalibrasi. Sensor yang dapat bekerja dengan baik yaitu sensor yang memiliki sifat linieritas yang baik, artinya nilai output dari sensor naik maupun turun sesuai dengan inputan. Untuk mencari tingkat linieritas dapat dilakukan dengan mencari koefisien korelasi antara input dan output sensor menggunakan metode regresi Linier.

1) Kalibrasi Sensor

Pada tahapan kalibrasi sensor dengan memberikan tegangan yang bervariasi ke sensor. $100 \mathrm{~V}-250 \mathrm{~V}$ tegangan bolak-balik dengan step tetap yaitu 5V. Hasil yang didapatkan sebagai berikut.

Tabel 1

Tabel kalibrasi sensor

\begin{tabular}{|c|c|c|}
\hline No & $\begin{array}{c}\text { Tegangan Input } \\
(\mathrm{V})\end{array}$ & $\begin{array}{c}\text { Tegangan peak to peak } \\
(\mathrm{V})\end{array}$ \\
\hline 1 & 100 & 556 \\
\hline 2 & 105 & 558 \\
\hline 3 & 110 & 559 \\
\hline 4 & 115 & 561 \\
\hline 5 & 120 & 563 \\
\hline 6 & 125 & 565 \\
\hline 7 & 130 & 567 \\
\hline 8 & 135 & 569 \\
\hline 9 & 140 & 571 \\
\hline 10 & 145 & 573 \\
\hline 11 & 150 & 575 \\
\hline 12 & 155 & 576 \\
\hline 13 & 160 & 578 \\
\hline 14 & 165 & 581 \\
\hline 15 & 170 & 583 \\
\hline 16 & 175 & 584 \\
\hline 17 & 180 & 586 \\
\hline 18 & 185 & 588 \\
\hline 19 & 190 & 590 \\
\hline 20 & 195 & 591 \\
\hline 21 & 200 & 593 \\
\hline & & \\
\hline
\end{tabular}

\begin{tabular}{|c|c|c|}
\hline No & $\begin{array}{c}\text { Tegangan Input } \\
(\mathrm{V})\end{array}$ & $\begin{array}{c}\text { Tegangan peak to peak } \\
(\mathrm{V})\end{array}$ \\
\hline 22 & 205 & 595 \\
\hline 23 & 210 & 597 \\
\hline 24 & 215 & 599 \\
\hline 25 & 220 & 601 \\
\hline 26 & 225 & 602 \\
\hline 27 & 230 & 605 \\
\hline 28 & 235 & 607 \\
\hline 29 & 240 & 608 \\
\hline 30 & 245 & 609 \\
\hline 31 & 250 & 611 \\
\hline
\end{tabular}

Berdasarkan tabel didapatkan grafik linieritas sensor tegangan dan persamaan linieritas dari sensor dengan menggunakan Microsoft Exel. Dalam pengujian linieritas variabel yang dicari adalah tegangan input terhadap tegangan output sensor tegangan.

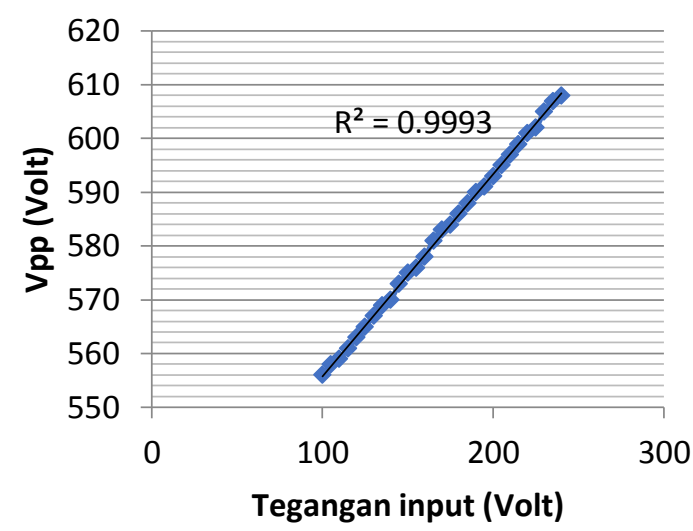

Gambar 9. Grafik Linieritas Sensor Tegangan

Dari gambar 9 dapat dilihat nilia $\mathrm{R}^{2}$ atau nilai korelasi untuk sensor tegangan adalah 0.9992, memiliki tingkat hubungan linieritas yang sangat tinggi. Dikatakan nilai linieritas sangat rendah dikarenakan nilai hubungan atau korelasi antara dua variabel yang dibandingkan antara pembacaan dari sensor dan tegangan input memiliki nilai korelasi antara 0.8 sampai dengan 1. Berdasarkan grafik dengan persamaan $\mathrm{y}=0.3763 \mathrm{x}+518.11$, digunakan untuk mengakses sensor.

2) Pengujian Sensor Tegangan

Pengujian ini dilakukan dengan mengukur tegangan dengan mengubahnya dari tegangan $150 \mathrm{~V}-250 \mathrm{~V}$, dengan membandingkan hasil pengukuran dari sensor terhadap Voltmeter digital. Hasil pengujian pada tabel 2.

Tabel 2

Data hasil pengujian sensor tegangan

\begin{tabular}{|c|c|c|c|}
\hline No & $\begin{array}{c}\text { Voltmeter } \\
(\mathrm{V})\end{array}$ & Sensor (V) & Error (\%) \\
\hline 1 & 152 & 152 & 0 \\
\hline 2 & 160 & 160 & 0 \\
\hline 3 & 170 & 170 & 0 \\
\hline 4 & 181 & 181 & 0 \\
\hline 5 & 190 & 190 & 0 \\
\hline 6 & 200 & 201 & 0.497 \\
\hline 7 & 210 & 211 & 0.473 \\
\hline
\end{tabular}




\begin{tabular}{|c|l|l|c|}
\hline 8 & 221 & 222 & 0.450 \\
\hline 9 & 230 & 230 & 0 \\
\hline 10 & 240 & 241 & 0.41 \\
\hline 11 & 251 & 251 & 0 \\
\hline \multicolumn{3}{|c|}{ Rata-rata } & 0.181 \\
\hline
\end{tabular}

Nilai presentasi kesalahan (Error) dalam pengujian sensor tegangan tersebut dengan error rata-rata adalah $0.181 \%$ sehingga sensor tegangan yang sudah dikalibrasi dapat digunakan.

\section{B. Pengujian Zero Crossing Detector}

Pengujian ini untuk memastikan Zero Crossing Detector pada rangkaian bekerja dengan baik dengan menampilkan gelombang output dari rangkaian. Dapat dilihat pada gambar 10 .

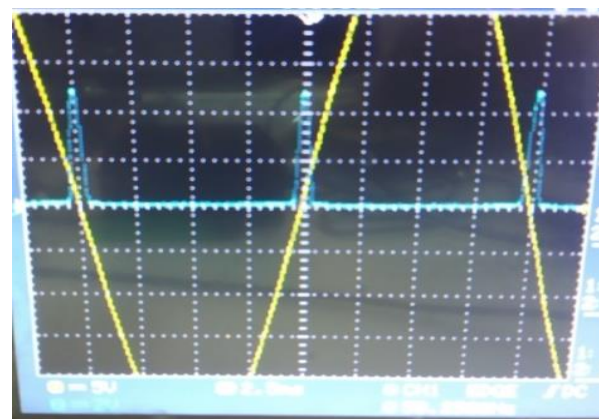

Gambar 10. Gelomban zerro crossing detector dan sinusoidal 220 Volt

Pada gambar diatas zero crossing ditunjukkan pada gelombang bewarna biru dan berwana kuning merupakan tegangan AC. Zero crossing mencari persilangan nol dengan tegangan $5 \mathrm{VDC}$, frekuensi $50 \mathrm{~Hz}$. Zero crossing detector mendeteksi persilangan nol setiap setegah gelombang.

C. Pengujian Keluaran Dimmer

Pengujian Dimmer disini dengan mengubah-ubah nilai PWM dan mengukur outputnya dengan osiloskop. Pengujian ini bertujuan untuk mengetahui apakah output dari dimmer sudah bekerja dengan baik dengan menghitung nilai frekuensi dan tegangan dimmer dari gelombang output osiloskop. Adapun hasil pengujian sebagai berikut.

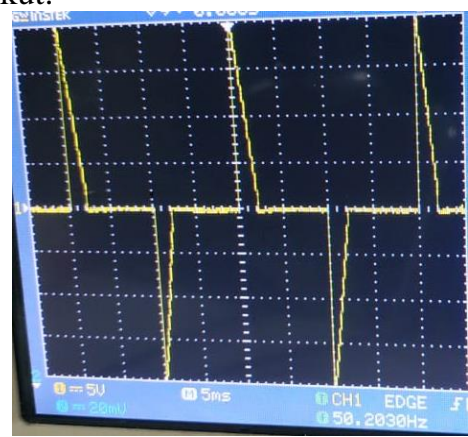

Gambar 11. Output dimmer duty cycle 45\%

Menghitung nilai periode dengan :

$\mathrm{T}=\sum$ kotak Horizontal $\times$ Time $/$ div

$$
\begin{aligned}
& =\sum \times \frac{5}{1 \times 10^{-3}} \\
& =0.02
\end{aligned}
$$

Menghitung nilai frekuensi dengan :

$\mathrm{f} \quad=\frac{1}{\mathrm{~T}}=\frac{1}{0.02}=50 \mathrm{~Hz}$

Menghitung nilai tegangan puncak ke puncak:

$$
\begin{aligned}
\mathrm{Vpp} & =\sum \text { kotak Vertikal } \times \text { Volt } / \text { div } \\
& =8 \times 50 \\
& =400 \mathrm{~V}
\end{aligned}
$$

Menghitung nilai tegangan puncak dengan :

$\mathrm{Vp} \quad=\frac{V_{p p}}{2}=\frac{400}{2}=200 \mathrm{~V}$

\begin{tabular}{|c|c|}
\hline Duty Cycle (\%) & Tegangan Output (V) \\
\hline 99 & 219 \\
\hline 95 & 218 \\
\hline 90 & 218 \\
\hline 85 & 217 \\
\hline 80 & 214 \\
\hline 75 & 210 \\
\hline 70 & 203 \\
\hline 65 & 192 \\
\hline 60 & 182 \\
\hline 55 & 170 \\
\hline 50 & 156 \\
\hline 45 & 142 \\
\hline 40 & 125 \\
\hline 35 & 106 \\
\hline 30 & 88 \\
\hline 25 & 69 \\
\hline 20 & 46 \\
\hline 15 & 35 \\
\hline 10 & 21 \\
\hline 5 & 10 \\
\hline
\end{tabular}

Menghitung nilai tegangan asli dengan :

$$
\begin{aligned}
\mathrm{Vrms} & =\mathrm{Vp} \times \sqrt{2} \\
& =200 \times \sqrt{2} \\
& =141.42 \mathrm{~V}
\end{aligned}
$$

Tabel 3

Hasil keluaran PWM

Grafik pada gambar 10 merupakan hasil dari data tabel 3

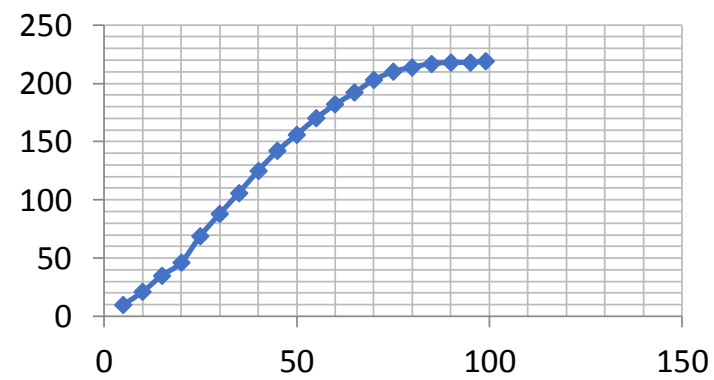

Gambar 12. Grafik hubungan Tegangan Keluaran dan Duty Cycle 
Pada pengujian, dimmer dapat menurunkan tegangan sesuai dengan nilai duty cycle yang diberikan. Dimmer memotong gelombang sinusoidal tetapi tidak merubah nilai frekuensi yang ada sehingga dimmer dapat digunakan pada sistem.

D. Pengujian keseluruhan

Pada pengujian keseluruhan dengan alat ukur multimeter apakah keluaran dari sistem sudah sesuai dengan setpoint yang telah ditentukan masukkan yang digunakan 220-250. Berdasarkan pengujian ini didapatkan hasil pada tabel 4 .
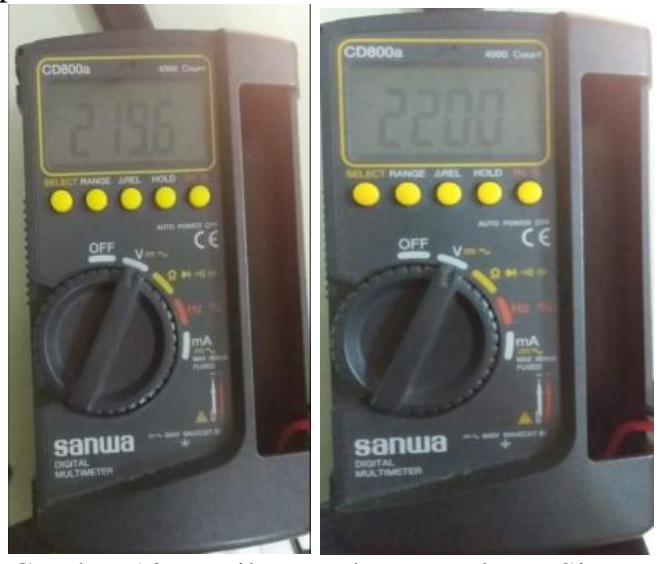

Gambar 13. Hasil Pengukuran Keluara Sistem

Tabel 4

Hasil pengukuran output sistem

\begin{tabular}{|c|c|}
\hline Tegangan Input $(\mathrm{V})$ & Tegangan Output $(\mathrm{V})$ \\
\hline 195 & 194 \\
\hline 198 & 197 \\
\hline 200 & 198 \\
\hline 220 & 219 \\
\hline 223 & 220 \\
\hline 226 & 220 \\
\hline 229 & 220 \\
\hline 232 & 219 \\
\hline 235 & 219 \\
\hline 238 & 219 \\
\hline 241 & 219 \\
\hline 244 & 219 \\
\hline 247 & 220 \\
\hline 250 & 219 \\
\hline
\end{tabular}

Berdasarkan data dari pengujian keseluruhan, sistem dapat berjalan sesuai dengan yang diinginkan. Dengan mengubah nilai input sistem dapat menurunkan tegangan berada pada setpoint yang diinginkan. Pada proses menghilangkan nilai error terjadi osilasi pada mikrokontroler. Walaupun terjadi osilasi tidak mempengaruhi cahaya lampu. Proses dari pengujian keseluruhan pada lampiran 4. Gambar 13 merupakan tampilan dari alat yang sudah disusun rapid an diuji.

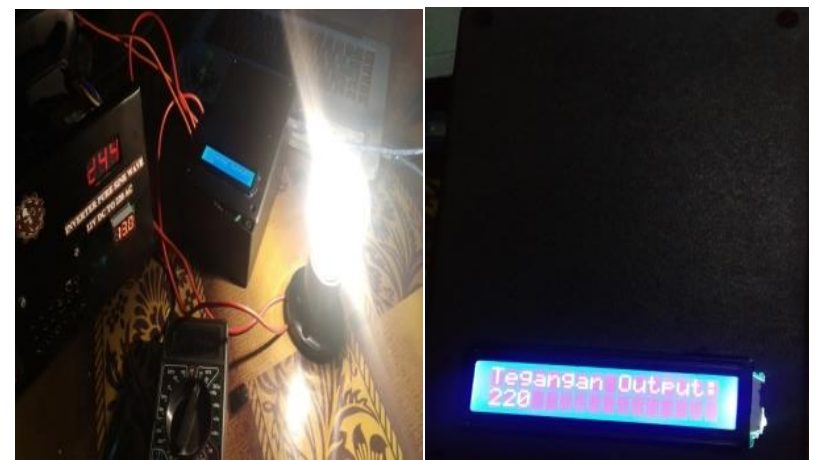

Gambar 14. Auto Voltage Regulator

\section{KESIMPULAN}

Dari percobaan dan pemabahasan pada bab sebelumnya didapat beberapa kesimpulan antara lain:

1) Penggunaan sensor ZMPT101B baik digunakan untuk pengukuran tegangan dimana memiliki sensitifitas tinggi.

2) Hasil dari kalibrasi sensor sudah linier dengan hasil pembacaan alat ukur dengan error rata-rata $0.181 \%$.

3) Perancangan dan program dari alat sudah sesuai dengan kebutuhan, berdasarkan hasil pengujian sistem dapat menurunkan tegangan.

4) Alat dapat bekerja dengan baik sesuai dengan yang diharapkan dimana ketika tegangan melebihi dari 220 VAC maka alat akan menurunkan tegangan secara otomatis.

\section{REFERENSI}

[1] Nurdin, A. A. (2018). Peranan Automatic Voltage Regulator Sebagai Pengendali Tegangan Generator Sinkron. Jurnal Ampere, 164-173.

[2] Kamal, A. M., \& Subhan. (2017). Penerapan Automatic Voltage Regulator pada. Seminar Nasional dan Expo Teknik Elektro (pp. 1-7). Aceh: Teknik Elektro Politeknik Negeri Lhokseumawe.

[3] Darmana, I. (2015). Perbaikan Jatuh Tegangan Dengan Pemasangan Automatic Voltage Regulator. Jurnal IPTEKS Terapan, 242-151.

[4] Habibnur, Y., Warsito, A., \& Setiawan, I. (2018). Perancangan Automatic Voltage Regulator (Avr) Berbasis Pengaturan Tegangan Catu Daya Arus Searah Inverter 1 Fase Sinusoidal Pulse Width Modulation (SPWM) Sinewave. TRANSIENT, 334340.

[5] Pamungkas, T. D., Haddin, M., \& Rijanto3, E. (2017). Modifikasi Topologi Pengendali PID untuk Automatic. JNTETI, 380-385.

[6] Ramadhani, A. (2014). Desain Model Sistem Eksitasi Type 1 Pada Generator Singkron Menggunakan Kontrol Fuzzy Logic. Jurnal intake, 10-18.

[7] Sandi, B. D., Hakim, L., \& Gusmedi, H. (2016). Studi Pemasangan Step Voltage Regulator dengan Model Injeksi Daya pada Jaringan Menengah $20 \mathrm{KV}$ Penyulang Katu Gardu Induk Menggala. ELECTRICIAN - Jurnal Rekayasa dan Teknologi Elektro, 129-139. 